ISSN 1991- 8690

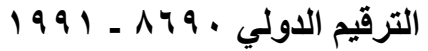

website :http:// jsci.utq.edu.iq

Email: utjsci@utq.edu.iq

\title{
Synthesis and Spectrophotometric Study of Some New Azodyes Derived From 4,5- diphenylimidazole
}

\section{Part I}

Asaad A.A

Montha .Kh.H

Chemistry Dept.. College of Educationfor Pure Science _ Basrah University. Iraq

\begin{abstract}
This study involves the preparation of three azodyes 2-( sulfapyridineazo)- 4,5-diphenyl imidazole (M1), 2-( 2arsonophenylazo)-4,5-diphenyl imidazole (M2) and 2-( sulfapyridineazo)- imidazole (M3), they have been described by C.H.N. , I.R. and Visible spectroscopic techniques. The acid-base properties were studied at different $\mathrm{pH}$ values $(0.65-12)$, then the ionization and protonation constants were determined. The solvents effect were studied at different solvents polarities
\end{abstract}

Key Words : 4,5-diphenylimidazole, Azodyes, Ionization \& Protonation constants and Spectral studies

$$
\text { تخليق ودراسة طيفية لبعض الصبغ الآزوية الجديدة المشتقة من ع ,ه - داي فنيل ايميدازول }
$$

الخلاصة

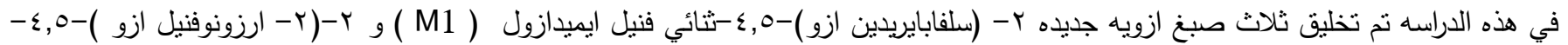

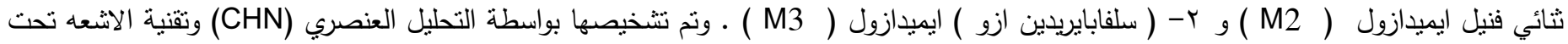

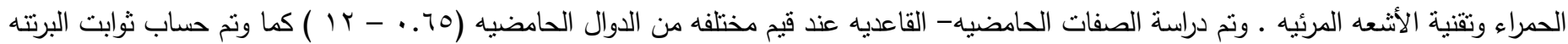
والتأين • ودرست تأثير مذيبات مختلفة القطبيه .

\section{1- Introduction}

The study of azo dyes with interesting physical and spectrophotometric properties have been active area of research . They are very important class of chemical compounds containing a heterocyclic moiety which have been attracted the attention of many researchers in the recent years[1]. They are highly colored and have been used as dyes and pigments for long years [2] .Synthetic azo dyes are among the most explored classes of organic compounds. Azo dyes are widely used in many practical applications such as photochromic materials, colorants, non-linear optics, sensors and indicators [3-6]. The azo dyes of heterocyclic compounds are regarded highly active towards most of the metal ions. They have great importance in chemical analysis because these compounds contain more than one active group[7-9].
This class of azo dyes being a ( $\pi$-acidic) azo imine system $(-\mathrm{N}=\mathrm{N}-\mathrm{C}=\mathrm{N}-)$ for this reason a number of these dyes were synthized and their abilities as chelating ligands $[10,11]$. Among the heterocyclic reagents 4,5diphenyl imidazole and imidazole dyes are extensively used for the spectrophotometric extraction of metal ions [12-14]. The o-arsenlic acid is widely used for analytical reagents for the determination of metals like Arsenazo I and Arsenazo III , and also used of some azodyes reagents [ 15،16]. The study of electronic spectra in different polarities of solvents may be given changes wavelength or intensity or shape of the absorption bands due to the interaction effect between solute and solvent [17].

\section{2- Experimental}

Double distilled water, and all the reagents and solvents were of reagent-grad quality . Infrared spectra ( 
in $\mathrm{KBr}$ pellets) were recorded on IR Affinity1shimadzu.Meltingpoint were determined on melting point apparatus. The dyes were recorded by using and element analysis (C.H.N.), they were carried out by perkin elemer 2400-11 element analysis. Visible absorption spactra were recorded by using LKB ( Biochrom ultra space II-4050 UV./V.) spectrophotometer .The $\mathrm{pH}$ measurements were made with pH-Meter (Trans Instruments Professional Benchtop BP3001 ). Accutate balance E-Mette Weender ( Land Strasse) 94-108.

\section{2-1 Diazotization}

0.005 mole of each aromatic amine sulfapyridine , o-Arsanic acid and sulfapyridine of weights 1.245 , 1.085 and $1.245 \mathrm{~g}$. respectively were dissolved in $3 \mathrm{ml}$ concentrated hydrochloric acid, then $20 \mathrm{ml}$ of distilled water to each salt forming. The solutions were cooled to $0-5$ Co in ice-bath $.5 \mathrm{ml}$ of sodium nitrite $0.4 \mathrm{~g}$. was then added drop wise with stirring continued to each solution to produce diazonium salt .

\section{2-2 Preparation of dyes M1 - M3}

0.005 mole of each 4,5-diphenyl imidazole , 4,5diphenyl imidazole and imidazole of weights $1.1,1.1$ and $0.34 \mathrm{~g}$. respectively were dissolved in $50 \mathrm{ml}$ alkaline ethanol . These solutions were added to the above diazonium salt solutions to forming sodium forms of the dyes M1 - M3 . The dyes solutions neutralized to the hydrogen forms by adding diluted hydrochloric acid by aid of $\mathrm{pH}$ paper. The precipitates were filtered off and twice recrystallized from 1:1ethanol : methanol mixture .

\section{2-3 Solutions}

- A stock solution of $\left(1 \times 10^{-3} \mathrm{M}\right)$ of each $\mathrm{M}_{1}, \mathrm{M}_{2}$ and $\mathrm{M}_{3}$ dye was prepared by dissolving an accurately weighed amount of the compounds in the required volume of ethanol, more dilute solutions were obtained by accurate dilution.

- Universal $\left(\mathrm{pH}_{2-12}\right)$ and Acetate $\left(\mathrm{pH}_{0.65-2}\right)$ buffer solutions [ 18 ] were prepared

\section{2-4 Procedure}

- Acid - Base studies (15) :To study the effect of $\mathrm{pH}$ values on the absorption spectra on the dyes M1-M3 and to determine the protonation and ionization constants, a series of buffer solutions ( acetate and universal ) were prepared with different $\mathrm{pH}$ values ( 0.65- 12 ).,with concentrations of dyes are $4 \times 10-5 \mathrm{M}$, the absorbance of these solutions was recorded at range of $(350-660 \mathrm{~nm}$. ) using a cell of $1 \mathrm{~cm}$. length and buffer solution as a blank solution ,. By the aid of half height method the constants were calculated.

- For solvent effect studies, A series of solutions of dyes ( M1-M3) were prepared of concentration of $4 \mathrm{x}$ 10-5 M in Ethanol, $\mathrm{H} 2 \mathrm{O}$, Methanol, Ethyl Acetate, Acetone , Dimethylformamid (DMF) and Dimethyl sulfoxide (DMSO) . The absorbance of these solutions were recorded at range of ( $350-600 \mathrm{~nm}$.) using cell of $1 \mathrm{~cm}$. length and using a solvent as a blank solution .

\section{3- Results and Discussion}

Some of the physical, chemical properties and C.H.N analysis of prepared dyes were illustrated in ( Table 1 )

Table 1- Some Physical Properties and Elemental analysis data for synthesized dyes

\begin{tabular}{||c|c|c|c|c|c|c|c|c|c|}
\hline \multirow{2}{*}{ Name } & $\begin{array}{c}\text { Chemical } \\
\text { Formula }\end{array}$ & $\begin{array}{c}\text { m.p. } \\
\left({ }^{\circ} \mathrm{C}\right)\end{array}$ & Color & \multicolumn{2}{|c|}{$\%$ c } & \multicolumn{2}{|c|}{$\% \mathrm{H}$} & \multicolumn{2}{c|}{$\%$ N } \\
\cline { 5 - 10 } & & & & Calc. & Found & Calc. & Found & Calc. & Found \\
\hline $\mathbf{M}_{1}$ & $\mathrm{C}_{26} \mathrm{H}_{20} \mathrm{~N}_{6} \mathrm{O}_{2} \mathrm{~S}$ & $163-165$ & Yellow & 64.98 & 65.10 & 4.20 & 4.53 & 17.49 & 17.25 \\
\hline $\mathbf{M}_{2}$ & $\mathrm{C}_{21} \mathrm{H}_{17} \mathrm{AsN}_{4} \mathrm{O}_{3}$ & $191-194$ & Yellow & 56.26 & 56.59 & 3.82 & 4.11 & 2.50 & 12.75 \\
\hline $\mathbf{M}_{3}$ & $\mathrm{C}_{14} \mathrm{H}_{12} \mathrm{~N}_{6} \mathrm{O}_{2} \mathrm{~S}$ & $170^{\circ} \mathrm{C}$ & Yellow & 51.21 & 51.53 & 3.68 & 3.92 & 25.59 & 25.81 \\
\hline
\end{tabular}

\section{IR Analysis :}

Table ( 2 ) shows the famous IR frequencies of important bands of functional groups frequencies as seen in Fig. ( 1 ).

Table (2)- The famous IR frequencies of important bands of azodyes M1 - M3

\begin{tabular}{|c|c|c|c|c|}
\hline AzoDyes & $\begin{array}{c}\mathbf{v} \\
(\mathrm{N}-\mathrm{H})\end{array}$ & $\begin{array}{c}\mathbf{v} \\
(\mathrm{C}=\mathrm{N})\end{array}$ & $\begin{array}{c}\mathbf{v} \\
(\mathrm{N}=\mathrm{N})\end{array}$ & $\begin{array}{c}\mathbf{v} \\
(\mathrm{O}=\mathrm{S}=\mathrm{O})\end{array}$ \\
\hline $\mathrm{M}_{1}$ & $3423 \mathrm{mb}$ & $1631 \mathrm{~S}$ & $1496 \mathrm{~m}$ & $1392 \mathrm{~m} \& 1138 \mathrm{~s}$ \\
\hline $\mathrm{M}_{2}$ & $3435 \mathrm{mb}$ & $1635 \mathrm{~m}$ & $1446 \mathrm{~m}$ & - \\
\hline $\mathrm{M}_{3}$ & $3485 \mathrm{mb}$ & $1631 \mathrm{~S}$ & $1463 \mathrm{~m}$ & $1390 \mathrm{~m} \& 1139 \mathrm{~s}$ \\
\hline
\end{tabular}

$\mathrm{b}=$ board, $\mathrm{s}=$ strong and $\mathrm{m}=$ med 


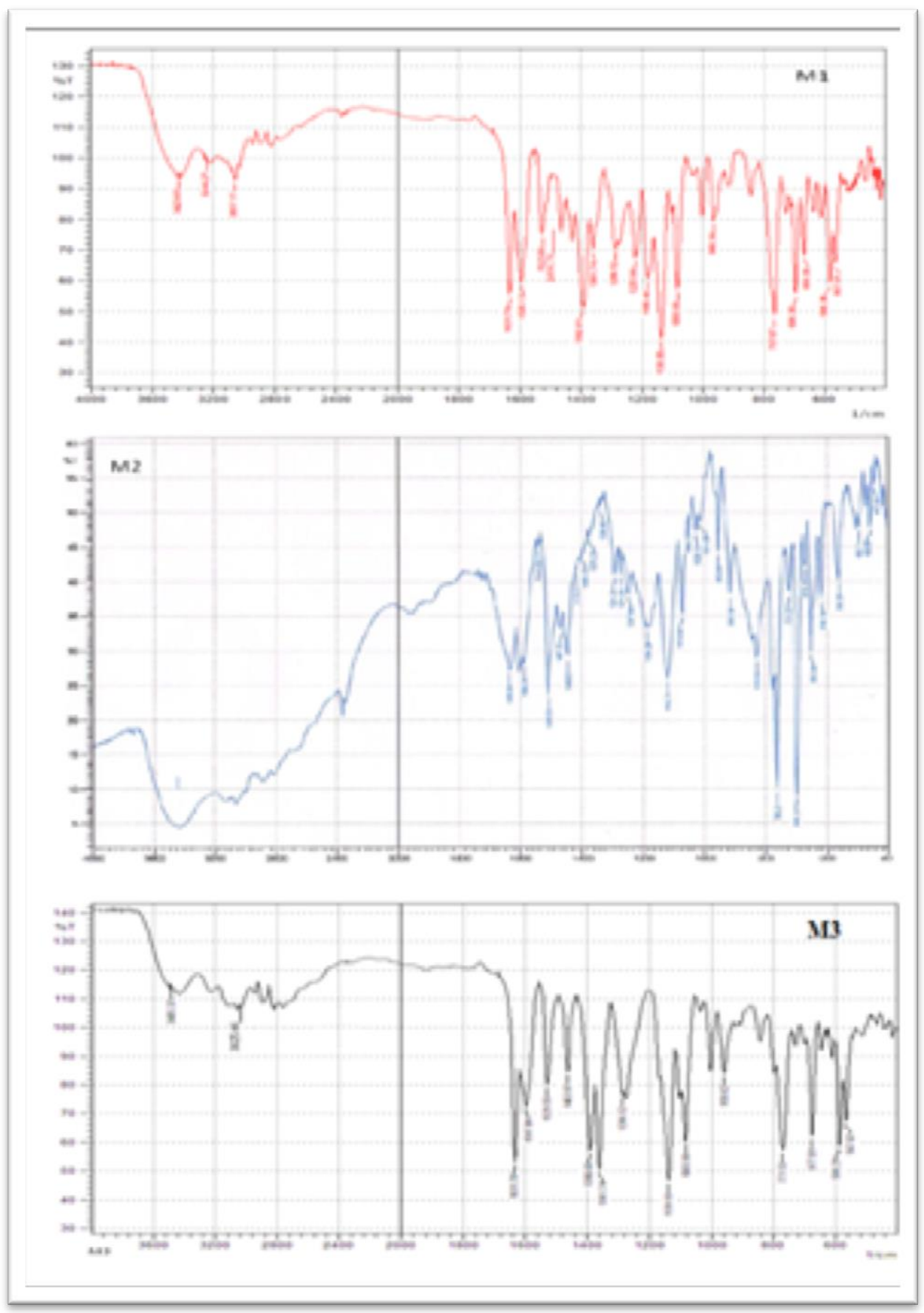

Fig.( 1 ) - IR spectra of the azodyes $M_{1}-M_{2}$

From IR analysis, Elemental analysis ( $\mathrm{CHN}$ ) and literatures and scientific previous researches, the chemical formula of azo dyes M1-M3 was suggested (schemes 1 ). 


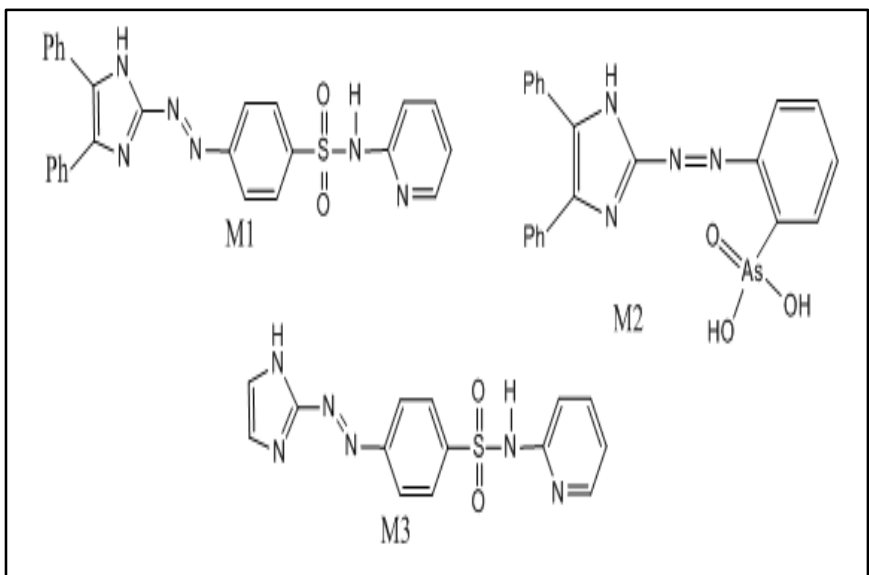

(schemes 1)

\section{Acid- Base Properties}

To see the effects of acidity and basicity of buffer solutions on the dyes and to calculate the ionization and protonation constants, a series of acetate and universal buffer solutions were prepared at different $\mathrm{pH}$ values [0.65-12] for each dye [19].The absorbance of dyes ( of total concn.4x10-5 M ) were measured in the range of ( $350-600 \mathrm{~nm}$.), using buffer solution of such $\mathrm{pH}$ value as a blank solution. For M1( Fig.2 ), the spectra characterized by two maximum bands at 490 $\mathrm{nm}$. in $\mathrm{pH}$ range $(8,10,11 \& 12)$ and at $440 \mathrm{~nm}$. for the other $\mathrm{pH}$ range. The first which more intense bands due to ionized form (basic form, anionic form ).And the second of $\mathrm{pH}$ range $(<7)$ related to protonation form ( acidic form, cationic form ).

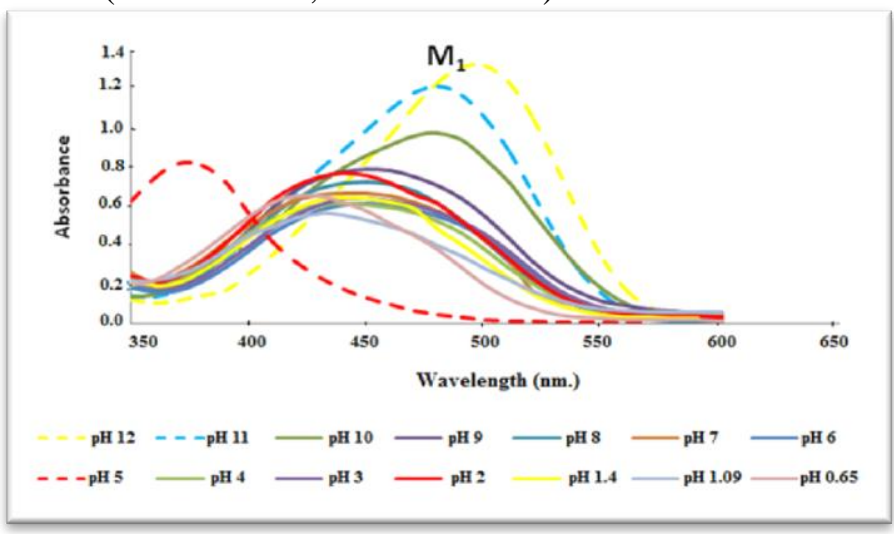

Fig.- 2: The electronic spectra of $\mathrm{M} 1$ at different $\mathrm{pH}$ values

For M2 ( Fig, 3 ), the spectra are also characterized by two maximum bands at $490 \mathrm{~nm}$. in $\mathrm{pH}$ range $(8,10,11$ $\& 12$ ) and at $440 \mathrm{~nm}$. for the other $\mathrm{pH}$ range . The first which less intense bands at $380 \mathrm{~nm}$., due to ionized form ( $\mathrm{pH}>6$ ), And the second of more intense at $360 \mathrm{~nm}$. of $\mathrm{pH}$ range $(<7)$ related to protonation form.

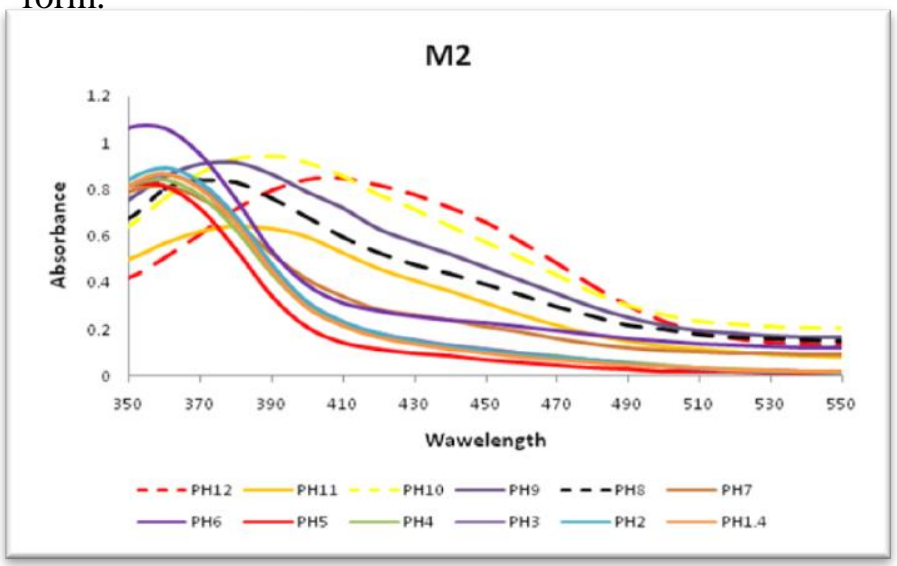

Fig.- 3 : The electronic spectra of $\mathrm{M} 2$ at different $\mathrm{pH}$ values

For M3 ( Fig. 4 ), at max. wavelength range ( 360-380 $\mathrm{nm}$. ) of acidic medium, this due to protonation. And the other wavelength max. in alkaline medium at 420 and $450 \mathrm{~nm}$.

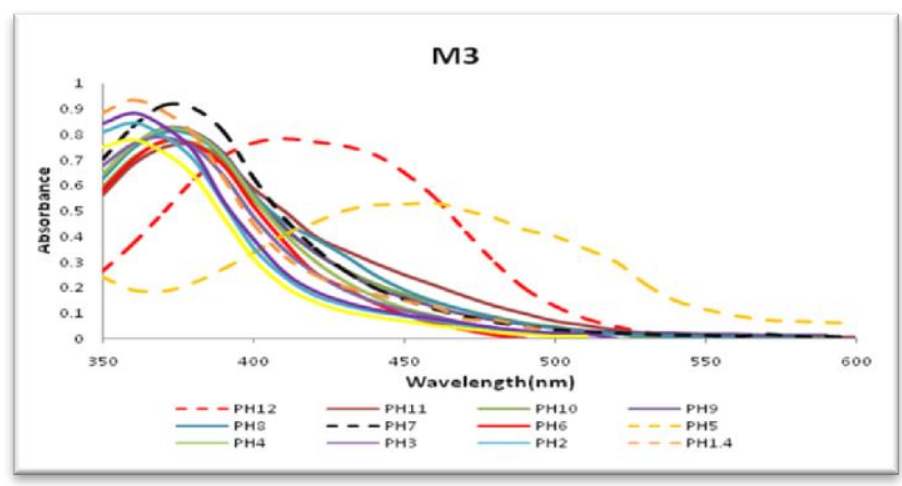

Fig.- 4: The electronic spectra of M3 at different $\mathrm{pH}$ values .

The ionization and protonation constants were calculated ( Table 3 ) by the aid of Figs. ( 2-4), the absorbance $-\mathrm{pH}$ curves were plotted ( Figs. 5-7 ).

From Absorbance - pH curve ( Figs. 5-7 for M1 - M3 ) and by the aid of height method the $\mathrm{pK}$ values were obtained by the relation :

$\mathrm{pK}=\mathrm{pH}($ at $\mathrm{A} 1 / 2) \quad$ where

$\mathrm{A} 1 / 2=(\mathrm{AL}+\mathrm{Amin}) /$.

Where AL and Amin are limiting and minimum absorbances respectively 
From Figs. 5-7 the mechanism of the ionization and protonation of each dye can be suggested ( schemes 2-4 )

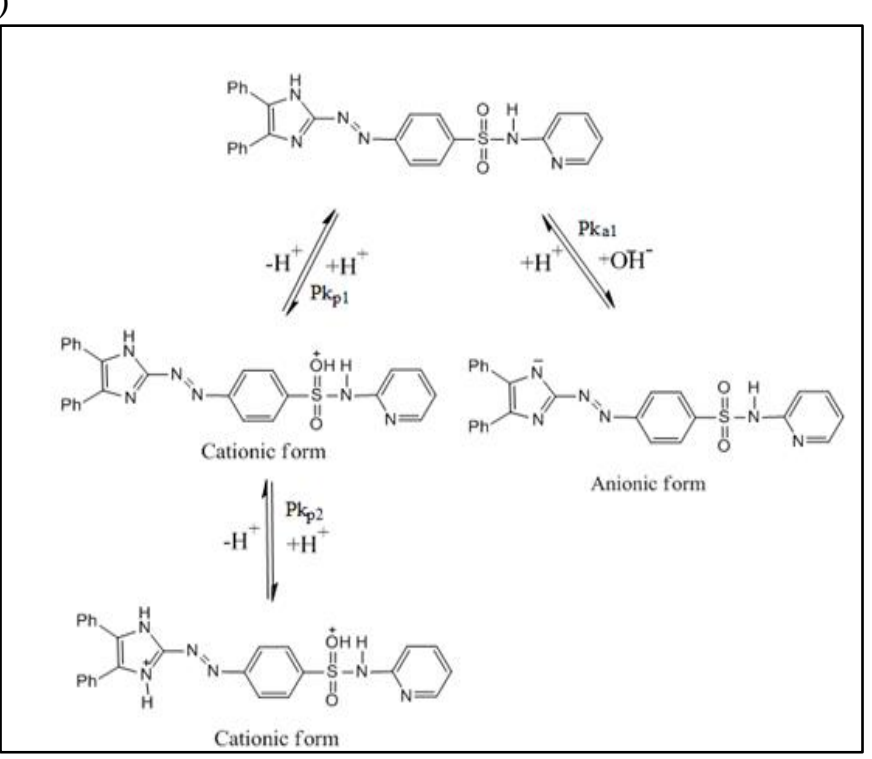

(schemes 2 )

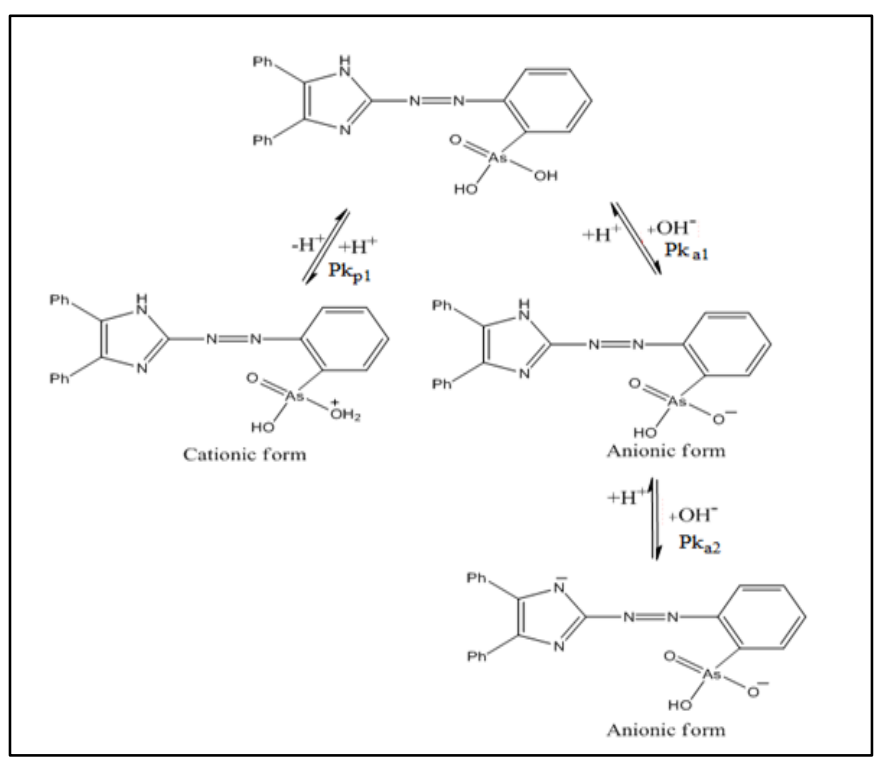

(schemes 3 )
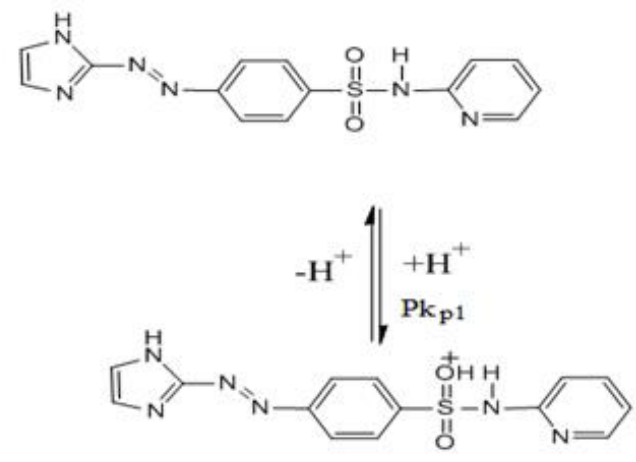

Cationic form
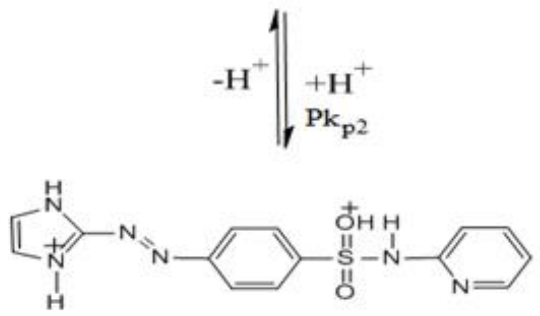

(schemes 4 )

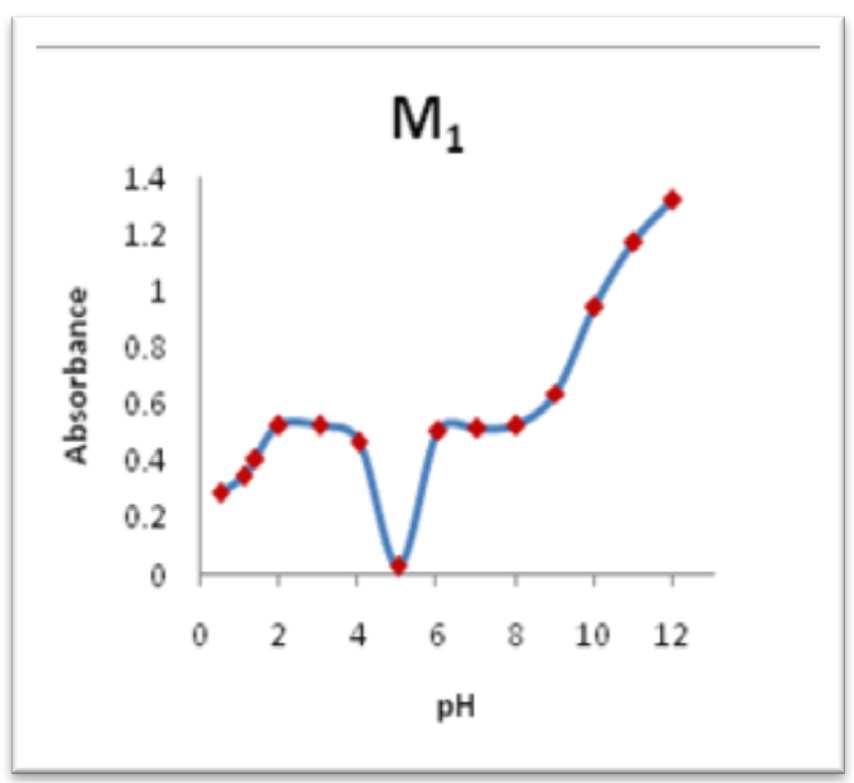

Fig.-5: $\mathrm{pH}$ - Absorbance curve for dye $\mathrm{M}_{1}$ 


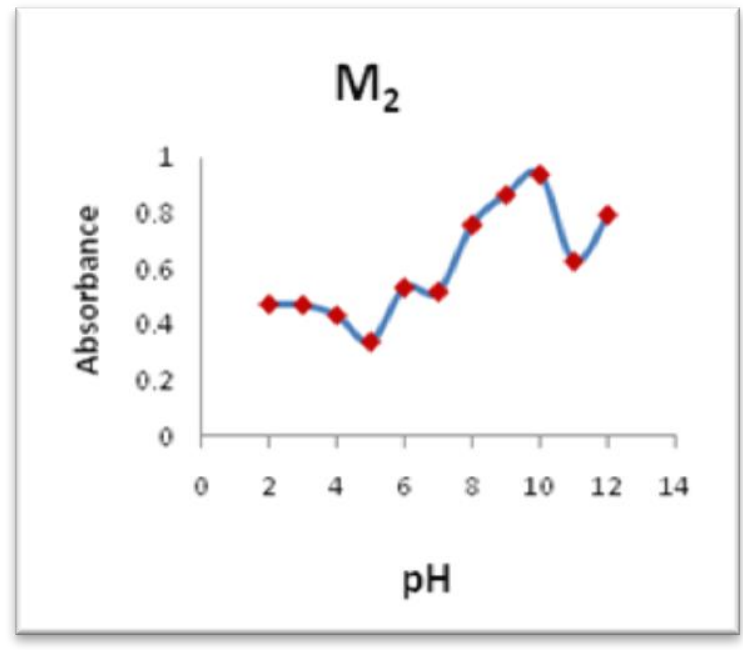

Fig.-6: $\mathrm{pH}-$ Absorbance curve for dye $\mathrm{M}_{2}$

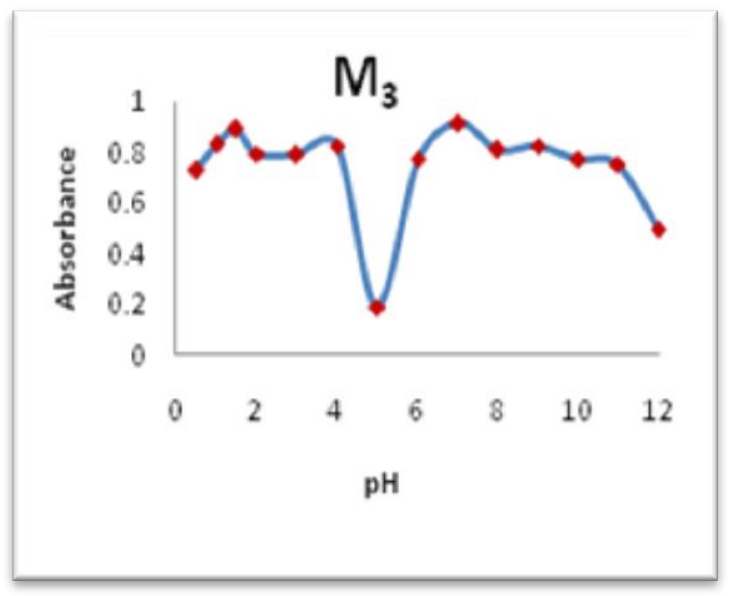

Fig.-7: pH-Absorbance curve for dye M3

Table-3 : The protonation ( $\mathrm{pK}_{\mathrm{p}}$ ) and ionization ( $\mathrm{pK}_{\mathrm{a}}$ ) constants of azodyes $\mathrm{M}_{1}-\mathrm{M}_{3}$

\begin{tabular}{|c|c|c|c|c|c|c|c|c|c|}
\hline Dye & $\begin{array}{c}\lambda_{\max } \\
\mathrm{nm}\end{array}$ & $\mathrm{A}_{1 / 2}$ & $\mathrm{pKp}_{1}$ & $\mathrm{~A}_{1 / 2}$ & $\mathrm{pKp}_{2}$ & $\mathrm{~A}_{1 / 2}$ & $\mathrm{pKa}_{1}$ & $\mathrm{~A}_{1 / 2}$ & $\mathrm{Pka}_{2}$ \\
\hline $\mathrm{M}_{1}$ & 490 & 0.4 & 1.4 & 0.27 & 5.6 & 0.91 & 10 & --- & - \\
\hline $\mathrm{M}_{2}$ & 380 & 0.44 & 5.5 & - & --- & 0.69 & 7.8 & 0.71 & 11.6 \\
\hline $\mathrm{M}_{3}$ & 370 & 0.81 & 0.9 & 0.48 & 5.7 & --- & - & - & - \\
\hline
\end{tabular}

\section{Band assignments and solvent effects}

Figs. ( 8-10) show the spectra of azodyes with strong bands $\lambda$ max at 450,370 and $380 \mathrm{~nm}$. for azodyes M1, M2 and M3 respectively, at different solvents of different polarities ( 1,4-dioxane , Ethyl acetate ,
Acetone, Methanol, Ethanol, DMF, DMSO and Water ).There are no any appearance shifts . The absorption spectra in various solvents are influenced by salvation and / or dielectric effects of solvents. To verify whether the band shift ( $\Delta v)$ is due to change in salvation energy or pure dielectric effects, the Gati and Szalay was used:

$\Delta v=\{(\mathrm{a}-\mathrm{b})[(\mathrm{n} 2-1) /(\mathrm{n} 2+1)]\}+\mathrm{b}[(\mathrm{D}-1) /($ $\mathrm{D}+1)]$

Where $\mathrm{n}$ and $\mathrm{D}$ are refractive index and dielectric constant of the medium, $\mathrm{a}$ and $\mathrm{b}$ are constants.

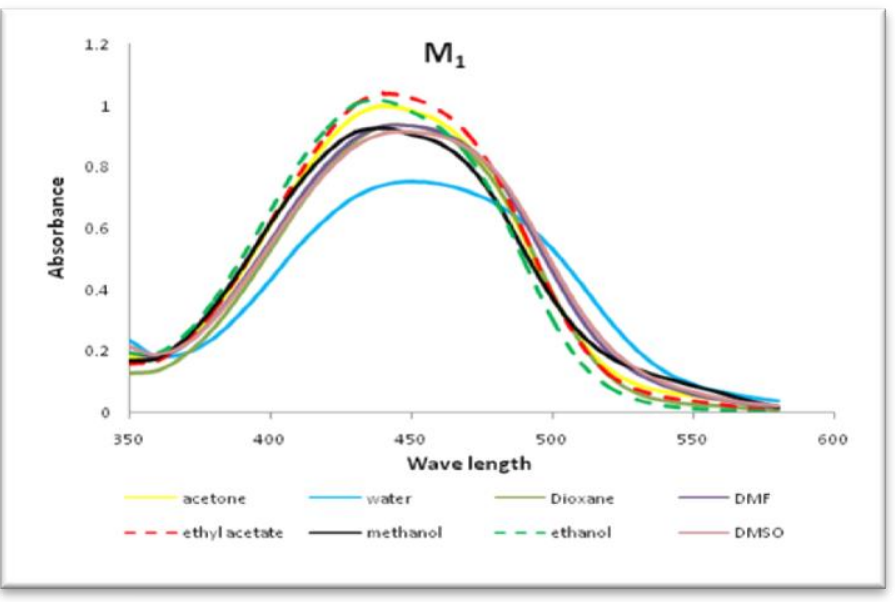

Fig.- 8: Absorption spectra of dye (M1) in various solvents

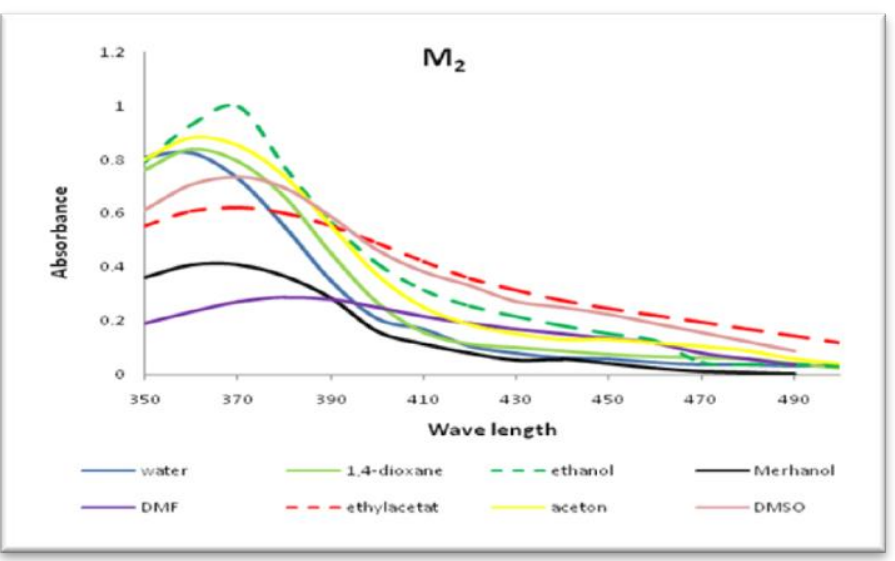

Fig.-9: Absorption spectra of dye (M2) in various solvents 


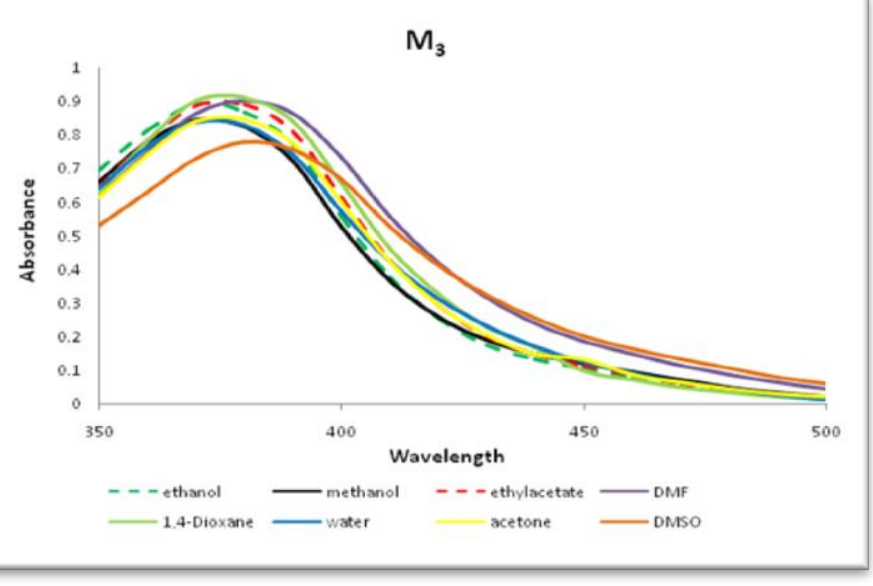

Fig.- 10: Absorption spectra of dye (M3) in various solvents

The plot of $\mathrm{f}(\mathrm{D})=[2(\mathrm{D}-1) /(2 \mathrm{D}+1)])$ against the $\lambda \max ($ Table 4 ) gives more or less linear relation with solvents of moderate polarities ( Fig.11).This denotes that the dielectric constant of the medium is the main factor governing the band shift in such solvents .

Table-4: The dielectric constants, dielectric function $\mathrm{f}(\mathrm{D})$ of solvents and $\lambda$ max of azodyes

\begin{tabular}{|c|c|c|c|c|c|c|}
\hline \multirow{2}{*}{ No. } & \multirow{2}{*}{ Solvent } & \multirow{2}{*}{$\mathbf{D}$} & \multirow{2}{*}{$\mathbf{f}(\mathbf{D})$} & \multicolumn{3}{|c|}{$\lambda$} \\
\cline { 5 - 7 } & & & & $\mathbf{M} 1$ & $\mathbf{M}$ & $\mathbf{m}$ \\
\hline 1 & 1,4 -dioxane & 2.30 & 0.464 & 440 & 360 & 380 \\
\hline 2 & Ethyl Acetate & 6.02 & 0.77 & 440 & 380 & 380 \\
\hline 3 & Acetone & 21.00 & 0.930 & 440 & 360 & 380 \\
\hline 4 & Methanol & 24.55 & 0.940 & 440 & 370 & 370 \\
\hline 5 & Ethanol & 32.70 & 0.955 & 440 & 370 & 370 \\
\hline 6 & DMF & 36.71 & 0.960 & 440 & 380 & 380 \\
\hline 7 & DMSO & 46.68 & 0.968 & 450 & 370 & 380 \\
\hline 8 & $\mathrm{H}_{2} \mathrm{O}$ & 78.30 & 0.981 & 450 & 360 & 370 \\
\hline
\end{tabular}

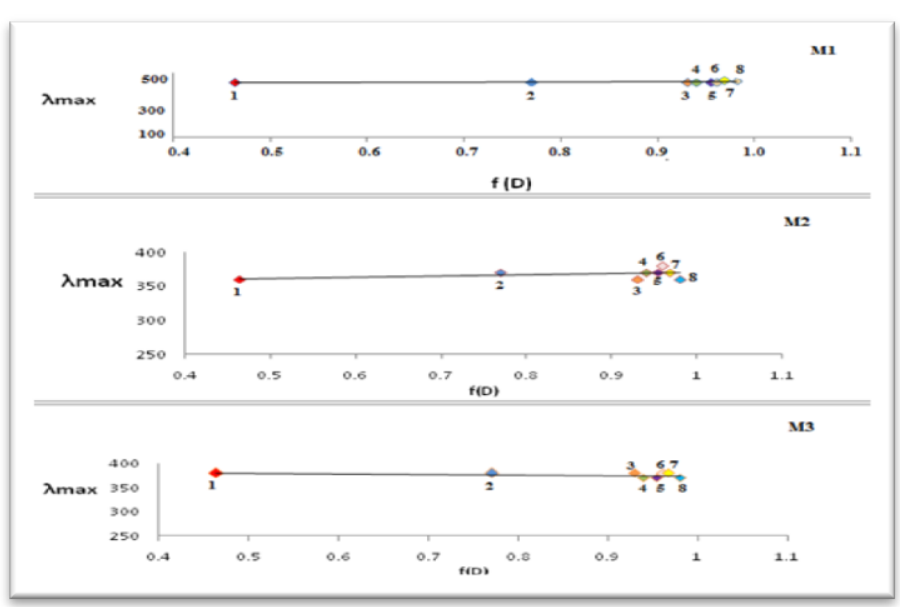

Fig.- 11: $\lambda \max$ With $f(D)$ for (M1 - M3) : Where ; 1=1,4dioxane, $2=$ ethyl acetate, $3=$ acetone, $4=$ methanol, 5= ethanol, $6=\mathrm{DMF}, \quad 7=\mathrm{DMS}, 8=$ water

\section{4- References}

1- $\quad$ Kirkan , and R.Gup ,R.,(2008),Turk J. Chem.,32, 9

2- Koh ,J.and Grreaves,A.J.,(2001), Dyes and Pigments, 50,117

3- El-Attar, Mona.A., ismail, Iqbal .M. and Ghoneim ,Mohamed .M.,J.,(2012),Braz .

Chem. Soc, 23,8

4- Steter, G.R., Potolio, J.O., Campos,M.L and Romero,J.R,(2008) J. Braz. Chem. Soc, 17, 660,(2008).

5- Oututu, J.O., Okoro,D.D. and Ossai, E.K.,(2008),J. applied science, $\mathbf{8 ,} 334$

6- Mallakpour, S. , Rafieman, F. and Faghihi,K.,(2007), Dyes and pigments $\mathbf{7 4 , 7 1 3}$

7- Reddy,B.K., Kumer, J.R. ,K.J.Reddy and ReddyA.V.,(2003),Chem.Anal.Sci. 4, 19

8- $\quad$ Tautkus, S.,(2004), Chem.Anal.(WarSaw),49,271

9- Wonless,Si-Eunlee andMi-Kyoungkim youngsang, kim.J.Bull. Koreanchem Soc,(2002) 23,1067

10- Mehdi, R.T. and AliA.M.,(2005), Nat. J. of Chem., 20, 540

11- Aladely,Kh.J.,Ali,A.M.andMehdi,R.T.,(2010),Na t.J. Chem.,38,311

12- Jawad,Sh.K., Ali,A.M. and.Hassan,A.Kh., (2010),J.Kufa.Chem.sci.,1,1

13- Jawad,S.K.,(2007),J. kerbala ,116,278

14- Jawad , S.K.,Ibtihaj,R.A., Abd Almuttalib,Z. , Abd Albaki,R. and Ahmed A.

H.,(2009) ,J. kufa. chem. Sci. , 35,427

15- Ali,A.A, Ph.D. Thesis ,(1984)" Analytical Applications Involving Iodide Ion and 8Quinolinol Azo Derivatives"

16- Al-Hijami,H.T., MSc.Thesis,(2011) " Preparation of Two New Azodyes Drevitatves and Studing Their Complexes Spectrophotometrically With $\mathrm{Fe}$ ( III), Cr ( III ) and VO2+"

17- Hardina,R. ,Lustinec,D. Stoln,P., Burgert,L., Lunak, S.and Holcopek,M.,(2004),Advance in color science and technology, 7,6

18- Dean,J.A. ,(1999)" Lunges Handbook of Chemistry", Mcgrawhill, ING. New York, 15 Ed.,

19- Ali,A.A., Fahad,T.A. Rusen, L.A and IMohamed,I.K.,(2008), J.Basrah Reseaecher (scicnce) ,34, , 48 